論文特集「フッ素の化学とその応用」

(日本化学会誌, 1985, (10), p. 1851 1853)

(C) 1985 The Chemical Society of Japan

\title{
溶融 $\mathrm{LiBeF}_{3}$ におけるフッ素の核磁気緩和
}

(1985 年 4 月 2 日受理)

松尾徹**大 野 英 雄*

$\mathrm{LiBeF}_{3}$ の溶融状態に叔斿る ${ }^{19} \mathrm{~F}$ の核スピン格子緩和時間 $\left(T_{1}\right)$ をパルス NMR 法によって測定し た。 $T_{1}$ の温度依存性を測定した結果, 約 $550^{\circ} \mathrm{C} に T_{1}$ の極少が現われた。これは $\left[\mathrm{BeF}_{4}\right]$ 錯イオン からフッ化物イオンが離脱し, 液中を拡散する機構によって説明される。フッ素の平均跳躍時間は $\tau=$ $1.9 \times 10^{-15} \exp \left(100 \times 10^{3} / R T\right) \mathrm{s}$ であった。融点直上の低温領域では, 別の機構, すなわち, $\left[\mathrm{BeF}_{4}\right]$ 錯イオンの回転による ${ }^{19} \mathrm{~F}$ の緩和が支配的であり, この領域での活性化ェネルギーは, 融体の粘性係数 の活性化エネルギー $58.5 \mathrm{~kJ} \cdot \mathrm{mol}^{-1}$ に近い值をもつ。

\section{1 概 説}

$\mathrm{LiF}-\mathrm{BeF}_{2}$ 系溶融塩のフッ素の自己拡散係数 $D$ の值は非常に大 きく，その活性化ェネルギーるまた，大きいことはよく知られて いる。すなわち， $\mathrm{LiBeF}_{3}$ 叔よび $\mathrm{Li}_{2} \mathrm{BeF}_{4}$ に拈けるフッ素の拡散 の活性化エネルギーはそれれ゙゙れ $122.9 \pm 16.3 \mathrm{~kJ} \cdot \mathrm{mol}^{-111}$ おょび $127.9 \pm 14.2 \mathrm{~kJ} \cdot \mathrm{mol}^{-12)}$ であって，ハロゲン化アルカリなどの 巣純な陰イオンの移拜に上る值 $20 \sim 30 \mathrm{~kJ} \cdot \mathrm{mol}^{-1}$ と比较して異 常に大きいことが知れる。

$\mathrm{X}$ 線解析によればか， $\mathrm{BeF}_{2}$ 量が多い組成領域において，固体で は無定形構造であるが溶液中では $\mathrm{BeF}_{2}$ の網目構造がかなり存在 しており， $\mathrm{BeF}_{2}$ 量が $65 \mathrm{~mol} \%$ より小さい領域では三次元的網 目構造が次第に弱まり, $\mathrm{LiBeF}_{3}$ 拉よび $\mathrm{Li}_{2} \mathrm{BeF}_{4}$ では三次元的 連結をるたない構造が考学られている。実際，溶融 $\mathrm{BeF}_{2}$ 中では ベリリウムは 4 個の最近接フッ素 $\left(\mathrm{Be}-\mathrm{F}\right.$ 距離 $: r_{\mathrm{BQ}-\mathrm{F}}=1.60 \AA ̊$ ) に囲まれそそれぞれのフッ素には 6 個の最近接フッ素が存在し， $\left[\mathrm{BeF}_{4}\right]$ を構成単位として頂点だをを共有した三次元的構造が発 達しているものと考光られる。これに等モルの $\mathrm{LiF}$ を加えた $\mathrm{LiBeF}_{3}$ では, ベリリウムは 4 個の最近接フッ素 $\left(r_{\mathrm{Be}-\mathrm{F}}=1.60 \AA\right)$ に囲まれているが，それどれのフッ素には平均として 3.6 個の最 近接フッ素 $\left(r_{\mathrm{F}-\mathrm{F}}=2.6 \AA\right)$ が存在していることが明らかにされ だ。この場合， 2 個の $\mathrm{BeF}_{4}$ 正四面体が頂点を共有しているもの とすればフッ素のまわりの最近接フッ素の平均個数は 3.4 とな り, 测定值 3.6 個にほぼ近い值が得られる3)。

一方，溶融 $\mathrm{Li}_{2} \mathrm{BeF}_{4}$ の場合には, ベリリウムは 4 個の最近接

日本原子力研究所然料工学部機能材料研究室, 319-11 茨 城紧那珂郡東海村

** 東洋大学工学部教盖謾程物理教室, 350 川越市你井中野 台

1) H. Ohno, K. Furukawa, Y. Tsunawaki, N. Umesaki, N. Iwamoto, J. Chem. Research(s), 1978, 158.

2) T. Ohmichi, H. Ohno, K. Furukawa, J. Phys. Chem., 80, 1628(1976).

3) F. Vaslow, A. H. Narten, J. Chem. Phys., 59, 4949 (1973).
フッ素 $\left(r_{\mathrm{Be}-\mathrm{F}}=1.60 \AA ̊ 丿\right)$ により囲まれ，それぞれのフッ素には 3 個の最近接フッ素 $\left(r_{\mathrm{F}-\mathrm{F}}=2.60 \AA\right)$ が存在することが示された。 これは $\mathrm{BeF}_{4}$ 四面体が単独で存在していることが多いことを意味 している。いずれの場合においても，比 $r_{F-F} / r_{B e-F}$ の值が理想的 な正四面体構造の值 1.63 にほ涪近いことから，フッ素は融液中 でははをんぞ正四面体 $\left[\mathrm{BeF}_{4}\right]^{2-}$ の移動によるとする単純な模型 ではその高い活性化エネルギーを説明できとうにないことは明ら かである。これに代わるるのとして，大野ら゙) は鑤イオンの回転 と, 錯イオン間の衝突炕て, 近接した錯イオン間のフッ素原 子の交換をともなら機構，または，LiFのような中性イオン対に よる払散の機構を提案した。

著者らは溶融 $\mathrm{Li}_{2} \mathrm{BeF}_{4}$ のフッ素の核スピンー格子緩和時間 $\left(T_{1}\right)$ の温度依存性とその解釉について報告したが58)，その中で，融液 中でフッ素は $\left[\mathrm{BeF}_{4}\right]^{2-}$ 錯イオンから熱的に解離し，比較的長い 距離を拡散したのち，ほかのフッ素空格子をもつ錯イオンにとら 兄られるとする模型が実験をよく説明することができることを示 した。また，錯イオンは球状イオンとして孤立しているよりる， 2 個の隣接錯イオンが頂点を共有している $\left[\mathrm{Be}_{2} \mathrm{~F}_{7}\right]^{3-}$ 錯イオンを つくりやすいこと。したがって, 完全な自由回転ではなく，制限 された回転が許されることを推論した。

本研究は既報5) $T_{1}$ 測定を行ない，その温度依存性を求め, フッ素の振舞いにつ いて検討し，また， $\mathrm{Li}_{2} \mathrm{BeF}_{4}$ の場合とくらべ比較榆討することを 目的とするすのである。

\section{2 実 験方 法}

純度 $6 \mathrm{~N}$ の $\mathrm{LiF}$ と $3 \mathrm{~N}$ の $\mathrm{BeF}_{2}$ を $1: 1$ の割合で混合し， 石英るつぼの内で溶融した母結晶から偏析着色部分をとりのぞ

4) 大野英雄, 綱脇恵章, 梅咲則正, 古川和男, 岩本信也, 日 本金属学会誌, 41, 391(1977).

5）松尾 徽, 鈴木秀次, 大野英雄, 古川和男, 日化, 1982, 892.

6) T. Matsuo, H. Ohno, J. Chem. Phys., 82, 3968 (1985). 


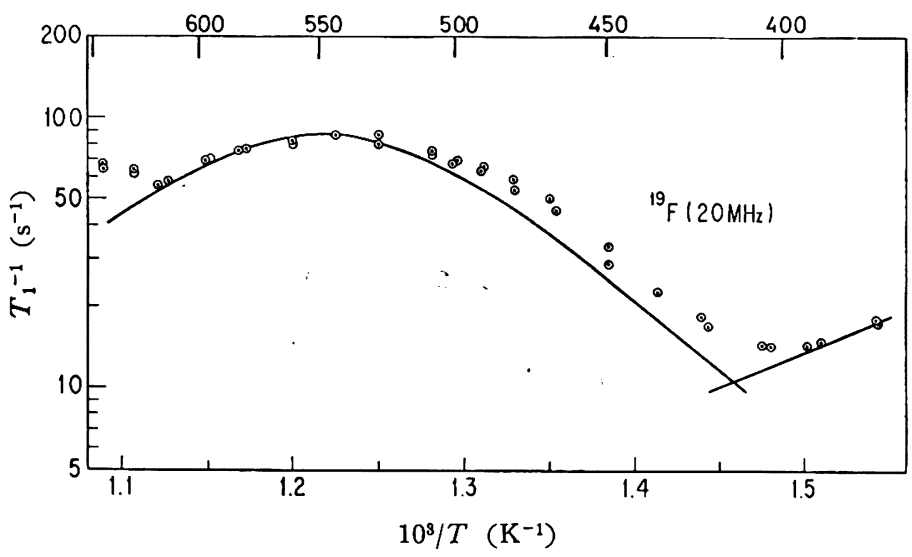

Fig. 1 Temperature dependence of $T_{1}{ }^{-1}$ of ${ }^{19} \mathrm{~F}$ in molten $\mathrm{LiBeF}_{3}$

き， $\mathrm{LiBeF}_{3}$ 試料とした。駆動 $\mathrm{RF}$ 電波の表皮効果を考虑し，こ れに等体積量の $\mathrm{Al}_{2} \mathrm{O}_{3}$ 高純度粉末を加えよく泥合したものを 10 $\mathrm{mm} \phi$ の石英管に真空封入し, NMR 試料とした。試料が溶融し たとき，微少融体球がたがいに接触しないようにするためであ る。試料中の常磁性不純物は核磁気緩和に大きな影響をおよぼ し，望ましくないので，前もって帯磁率測定を行ない，常磁性不 純物浱度を求めたところ， $\mathrm{Fe}^{2+}$ イオン換算で， $2.9 \mathrm{ppm}$ 以下で あり，その $T_{1}$ への影響は無視してよいと考えられる。

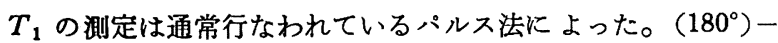
$\tau ー\left(90^{\circ}\right)$ のパルス列を試料に印加し，(90\%) パルスのすぐあとに つつく自由歳差信号 (FID) の強度 $I$ をパル間隔 $\tau$ の関数とし て剆定した。FID 強度は $I=I_{0}\left(1-2 \exp \left(-\tau / T_{1}\right)\right)$ の形に整理 することができ， $T_{1}$ が求められた。 $\mathrm{S} / \mathrm{N}$ 比向上のため信号 $I$ は 可算平均された。温度は $\mathrm{Pt}-\mathrm{Pt}(13 \% \mathrm{Rh})$ 熱電対により測定し， $\pm 1^{\circ} \mathrm{C}$ 以内に温度制御した。

\section{3 結果およひ考察}

因 1 に溶融 $\mathrm{LiBeF}_{3}$ に打ける ${ }^{19} \mathrm{~F}$ の $T_{1}{ }^{-1}$ (緩和率) の温度依 存性を示す。 $T_{1}{ }^{-1}$ は温度上昇につれ，初め少し減少するか，以 後増大し，極大を通ったのちふたたび減少する。この極大はいわ ゆる $T_{1}$ 極少と呼ばれるむのである。 $620^{\circ} \mathrm{C}$ 以上になると, 試料 と容器やフルミナとの反応が起こって, $T_{1}^{-1}$ の值はこの曲線か らずれる傾向にある。 $T_{1}$ 極少は約 $550^{\circ} \mathrm{C}$ で現われる。

${ }^{10} \mathrm{~F}$ の核スピンは $I=1 / 2$ であって，核四極子モーメントをむ たないから同種または異種核との相互作用は主として双極子相互 作用にかぎられる。しかし，フッ素は錯イオンを棈成しているか ら，錯イオンの回転による緩和や錯イオンを構成する他の原子と のスカラー結合による効果などを考虑する必要がある。しかし，

既報5)(て詳述したように, 溶融 $\mathrm{Li}_{2} \mathrm{BeF}_{4}$ のフッ素の緩和へのお むな奇与は, $\left[\mathrm{BeF}_{4}\right]^{2-}$ 錯イオンからのフッ化物イオンの解離と, 比離的長距離におよぶ融夜中でのフッ化物イオンの拡散の効果で あることが示された。

図 2 に既報卓8)から引用した溶融 $\mathrm{Li}_{2} \mathrm{BeF}_{4}$ における ${ }^{19} \mathrm{~F} の T_{1}^{-1}$ の温度依存性を二つの周波数について測定した結果を示す。困 1 の $\mathrm{LiBeF}_{3}$ の ${ }^{19} \mathrm{~F}$ の $T_{1}{ }^{-1}$ と比較してみると雨者はほぼ同じ值 と形状をもつことがわかる。これから， ${ }^{19} \mathrm{~F}$ の綬和について既

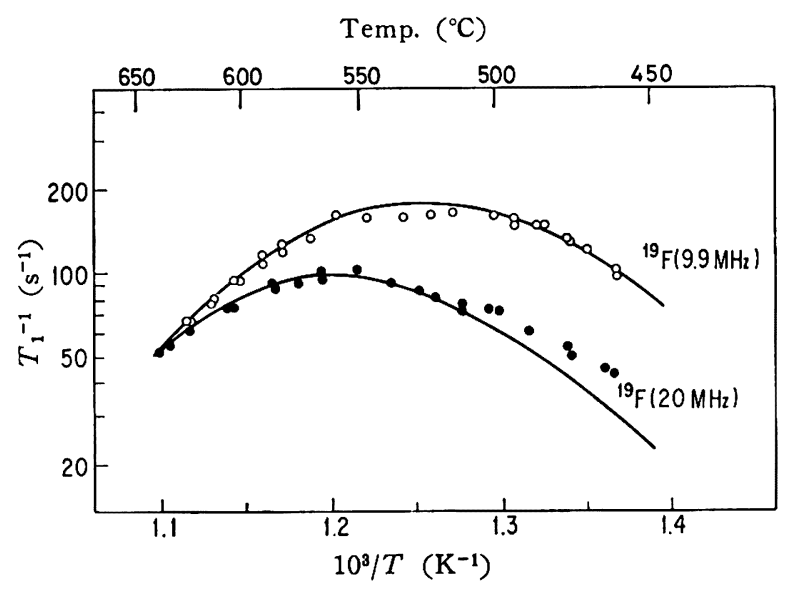

Fig. 2 Temperature dependence of $T_{1}{ }^{-1}$ of ${ }^{19} \mathrm{~F}$ in molten $\mathrm{Li}_{2}\left[\mathrm{BeF}_{4}\right]^{5)(8)}$

報5)(で述べた議論に基づき，溶融 $\mathrm{LiBeF}_{3}$ と $\mathrm{Li}_{2} \mathrm{BeF}_{4}$ における フッ素の拻散機構ならびに $T{ }_{1}$ への寄与について同一のモデルが 成立つものと考兄られる。

四1の上に凸の実線は

$$
T_{1}^{-1}=S_{0}\left(\omega /\left(1+\omega^{2} \tau^{2}\right)+4 \omega /\left(1+4 \omega^{2} \tau^{2}\right)\right)\left(\mathrm{s}^{-1}\right)
$$

の理論式7)を用い，測定値にもっとも合らように $S_{0}$ とを調節 して描いたものである。このとき ${ }^{19} \mathrm{~F}$ の跳躍時間(または ${ }^{19} \mathrm{~F}$ の双極子相互作用の相関時間) $\tau$ として, $\tau=\tau_{0} \exp (E / R T)$ と 仮定すれば，

$$
\tau=1.9 \times 10^{-15} \exp \left(100 \times 10^{3} / R T\right)(\mathrm{s})
$$

が得られる。ここで $T_{1}^{-1}$ のピークは（1）式により $\omega \tau=0.64$ で与えられることを用いた。

溶融 $\mathrm{LiBeF}_{3}$ の $T_{1}^{-1}$ の温度依存性において, $400^{\circ} \mathrm{C}$ 以下の様 子は $\mathrm{Li}_{2} \mathrm{BeF}_{4}$ の場合にくらべ多少買なっていて，直線部分で近 似できる。この部分は温度籁围がかきられているので正確な勾配 は求まらないが，図 1 の右上りの值線は溶融 $\mathrm{LiBeF}_{3}$ の粘性係数 の活性化ェネルギー $\left.58.5 \mathrm{k} \mathrm{J} \cdot \mathrm{mol}^{-1} 8\right)$ の勾配で引いたものであ

7) H. C. Torry, Phys. Rev., 92, 962(1953). 
る。ほぼ拣蹒値に合っている。これからこの直線部分の緩和機

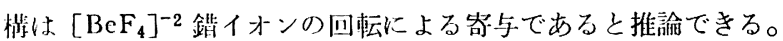
錯イオンの回転の相関時間はStokesの定理にしたがえば，融液

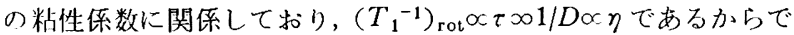
ある。ここで， 既報5で述べられているように $\omega \tau \ll 1$ とした。観 測された全緩和率 $T_{1}^{-1}$ は, 前に述べたフッ素の拡散からの寄与 $\left(T_{1}{ }^{-1}\right)_{\mathrm{d} 1 \mathrm{fr}}$ とここで述べた回転の寄与 $\left(T_{1}^{-1}\right)_{\text {rot }}$ から

$$
T_{1}^{-1}=\left(T_{1}^{-1}\right)_{\text {diff }}+\left(T_{1}^{-1}\right)_{\text {rot }}
$$

で与えられる。

溶融 $\mathrm{LiBeF}_{3}$ におけるフッ素の拡散は，概説で述べたような $\left[\mathrm{BeF}_{4}\right]$ 錯イオンの回転と隣接錯イオン間のフッ素の相互交換と いら模型では説明できそうにない。なぜなら，1回のフッ素の交 換のための跳躍でフッ化物イオンの動く距離は高々イオン間距離 の 2 倍, すなわち $6 \AA$ 程度であり, Stokes の定理 $D=\left\langle a^{2}\right\rangle /$ $6 \tau$ の関係と， $D$ (自己払散係数) の測定值から得られる跳躍時 間 $\tau$ の值は $\tau \approx 10^{-11} \mathrm{~s}$ のオーダーとなる。これは NMR から得 られた $\tau \simeq 10^{-8} \sim 10^{-9} \mathrm{~s}$ よりもずっと短く, 鍇イオンの回転の相 関時間程度になってしまらからである。よって, フッ素は錯イオ ンから解離したのち比較的長い距離融体中を拡散し, 他の錯イオ ンにとらえられるとする模型の方がいと思われる。

ここで得られたフッ素の跳躍の活性化エネルギー $100 \mathrm{~kJ} \cdot \mathrm{mol}^{-1}$ は拡散係数の活性化エネルギー $122.9 \pm 16.3 \mathrm{~kJ} \cdot \mathrm{mol}^{-1}$ に近い。 また $\mathrm{Li}_{2} \mathrm{BeF}_{4}$ のフッ素の $\mathrm{NMR}$ から得られた值 $104 \mathrm{~kJ} \cdot \mathrm{mol}^{-1}$ とほぼ等しい。溶融 $\mathrm{Li}_{2} \mathrm{BeF}_{4}$ と $\mathrm{LiBeF}_{3}$ とをくらべてみると， X線回折によれば構造上若干の差異が認められるが，その差は ${ }^{19} \mathrm{~F}$ の核緩和率にほとんど影響がないように思われる。フッ素の

8) S. Cantor, W. T. Ward, C. T. Moyniham, J. Chem. Phys., 50, 2874(1969).
扗散機篮，跳躍時間，活性化エネルギーなどもきわたっった差はな い。

融体中に㧊いて， $\mathrm{Li}^{+}$イオンの運動はより容易であり，電気伝 简度はほとんと $\mathrm{Li}^{+}$イオンの払散できめられていで $\mathrm{F}^{-}$の渝率 は小さい。このことと, フッ素の拡散係数が大きいこととは矛 盾するよらに思える。しかし, 融体中で解離した $\mathrm{F}^{-}$イオンと $\mathrm{Li}^{+}$イオンは結合して $\mathrm{Li}^{+} \mathrm{F}^{-}$の中性イオン対となって払散する 可能性を考えることにより解釈されるたろう。

\section{4 結語}

溶融 $\mathrm{LiBeF}_{3}$ における ${ }^{19} \mathrm{~F}$ の $T_{1}^{-1}$ の温度依存性は約 $550^{\circ} \mathrm{C}$ に極大をもつ曲線で表わされ， $T_{1}^{-1}$ への寄与は主として，フッ 素の払散によるものである。また，低温側には錯イオン $\left[\mathrm{BeF}_{4}\right]^{2-}$ の回転による寄与として一部直線部分が現われる。

フッ素の拡散は錯イオンからフッ素が解離し，長い距離融体中 を払散し，他の錯イオンにとらえられる機構により行なわれる。 融体中の拻散は $\mathrm{Li}^{+} \mathrm{F}^{-}$の中性イオン対の形で行なわれる可能性 が強い。

溶融 $\mathrm{Li}_{2} \mathrm{BeF}_{4}$ の ${ }^{19} \mathrm{~F}$ の $T_{1}$ と比較した結果, フッ素の払散機 構，跳躍時間にきわだった差異はみとめられない。

溶融 $\mathrm{LiBeF}_{3}$ におけるフッ素の跳躍時間 $\tau$ は $\tau=1.9 \times 10^{-15}$ $\exp \left(100 \times 10^{3} / R T\right)$ で与えられる。

本研究は原研施設共同利用研究のらちの協力研究として，また 東京大学原子力センター共同利用施設の利用により行なわれたも のである。関係各位に深く感謝します。

9) N. Iwamoto, Y. Tsunawaki, N. Umesaki, H. Ohno, K. Furukawa, J. Chem. Soc., Faraday Trans. 2, 75, 1277(1979).

\title{
Special Articles on Fluorine Chemistry and Its Application
}

\author{
Nuclear Spin Relaxation of Fluorine in Molten $\mathrm{LiBeF}_{3}$ \\ Toru Matsuo** and Hideo Ohno* \\ Function Materials Laboratory, Department of Nuclear Fuels and Materials \\ Research, Japan Atomic Energy Research Institute; Tokai-mura, \\ Naka-gun, Ibaraki 319-11 Japan \\ ** Institute of Physics, Faculty of Engineering, Toyo University; Kawagoe- \\ shi 350 Japan
}

The spin lattice relaxation time $\left(T_{1}\right)$ of ${ }^{19} \mathrm{~F}$-nuclear spin in molten $\mathrm{LiBeF}_{3}$ was measured at frequency of $20 \mathrm{MHz}$ by means of the pulse NMR technique. $T_{1}$ becomes a minimum at about $550^{\circ} \mathrm{C}$ and $T_{1}^{-1}$ can be expressed as $\tau /\left(1+\omega^{2} \tau^{2}\right)$, where $\tau$ is the correlation time and is estimated to be $1.9 \times 10^{-15} \exp \left(100 \times 10^{3} / R T\right) \mathrm{s}$. It is suggested that the relaxation mechanism of ${ }^{19} \mathrm{~F}$ - in molten $\mathrm{LiBeF}_{3}$ is due to the dissociation of $\mathrm{F}$ ions from $\left[\mathrm{BeF}_{4}\right.$ ] complex ions and the long distance diffusion of $\mathrm{F}$ ions in the liquid. At lower temperature the other mechanism prevails, that is, the main contribution to $T_{1}^{-1}$ is the rotation of the complex ions. 